Vol II. No. 1, September 2017, hlm. 1 - 7

Available online at www.jurnal.una.ac.id/indeks/jmp

\title{
PENINGKATAN KEMAMPUAN PEMECAHAN MASALAH MATEMATIS SISWA SMP PERCUT SEI TUAN MELALUI PEMBELAJARAN KOOPERATIF TIPE STAD
}

\author{
Tanti Jumaisyaroh Siregar \\ Pendidikan matematika, Universitas Muslim Nusantara Al-Washliyah Medan \\ Email:tanti.jss@gmail.com
}

\begin{abstract}
The purpose of this research was to know: the difference of improvement in mathematical problem solving ability of students that given cooperative learning type STAD with students that given direct learning. The type of this research was quasi - experimental research. Variable of this research consist of independent variable was cooperative learning model type STAD and while dependent variable was mathematical problem solving ability of students. The population of this research is all students of SMP Swasta Al-Maksum Percut Sei Tuan and the sample of this research is grade eight with taken sample two classes (experiment and control), they are 66 students where class VIII-2 as experiment-class and class VIII-3 as control-class. The instrument of this research were: test of mathematical problem solving and then The analysis data was done by using tTest. Based of the results analysis, it showed that: improvement of the students' ability in mathematical problem solving that given cooperative learning type STAD was higher than the students' ability that given direct learning. His then, cooperative learning type STAD suggested that be used as an alternative for mathematic teacher to improved students' ability in mathematical problem solving.
\end{abstract}

Keywords: Problem Solving, Cooperative Learning Type STAD.

\begin{abstract}
Abstrak
Tujuan penelitian ini untuk mengetahui: perbedaan peningkatan kemampuan pemecahan masalah matematis antara siswa yang diberi pembelajaran kooperatif tipe STAD dengan siswa yang diberi pembelajaran langsung. Jenis penelitian ini merupakan penelitian eksperimen semu. Variabel penelitian ini terdiri atas variabel bebas yaitu model pembelajaran kooperatif tipe STAD sedangkan variabel terikatnya yaitu kemampuan pemecahan masalah matematis siswa. Populasi dalam penelitian ini adalah seluruh siswa SMP Swasta Al-Maksum Percut Sei Tuan dan sampel dalam penelitian ini adalah siswa kelas VIII dengan mengambil dua kelas secara acak (kelas eksperimen dan kelas kontrol) sebanyak 66 orang dimana kelas VIII-2 sebagai kelas eksperimen dan kelas VIII-3 sebagai kelas kontrol. Instrumen yang digunakan terdiri dari tes kemampuan pemecahan masalah matematis selanjutnya data dianalisis dengan uji t. Berdasarkan hasil analisis tersebut diperoleh yaitu: peningkatan kemampuan pemecahan masalah matematis siswa yang diberi pembelajaran kooperatif tipe STAD lebih tinggi daripada siswa yang diberi pembelajaran langsung. Oleh karena itu,disarankan agar kooperatif tipe STAD dijadikan alternatif bagi guru untuk meningkatkan kemampuan berpikir pemecahan masalah matematis siswa.
\end{abstract}

Kata Kunci: Pemecahan Masalah Matematis, Pembelajaran Kooperatif Tipe

STAD 


\section{MATEMATICS PAEDAGOGIC}

Vol II. No. 1, September 2017, hlm. 1 - 7

Available online at www.jurnal.una.ac.id/indeks/jmp

Salah satu tujuan mata pelajaran matematika diberikan di sekolah adalah siswa memiliki kemampuan pemecahan masalah matematis. Pemecahan masalah merupakan komponen yang penting dalam matematika sebab tujuan belajar yang ingin dicapai dalam pemecahan masalah berkaitan dengan kehidupan sehari-hari (Susanto, 2013: 196). Dalam hal ini disebabkan karena dalam kehidupan sehari-hari siswa tidak terlepas dari masalah.

Namun

kenyataannya, berdasarkan hasil penelitian Sari dkk (2014) menunjukkan bahwa masih rendahnya rata-rata kemampuan pemecahan masalah matematis siswa kelas VIII SMP di Padang. Berdasarkan tes yang diberikan, diketahui bahwa 23 orang siswa belum mampu menyelesaikan soal pemecahan masalah secara tepat, sehingga dapat disimpulkan bahwa kemampuan pemecahan masalah matematika siswa masih rendah.

Kemampuan pemecahan masalah matematis siswa yang masih rendah disebabkan oleh beberapa faktor salah satunya pembelajaran yang dilakukan oleh guru yang mana selama ini guru masih kurang tepat memilih dan menggunakan model pembelajaran yang sesuai dalam menyampaikan materi dan tujuan pembelajaran. Dalam pembelajaran matematika, guru kebanyakan menerapkan pembelajaran langsung.

Pada pembelajaran langsung merupakan pembelajaran dimana guru bertindak sebagai pemimpin sekaligus fasilitator belajar, sedangkan siswa berperan sebagai individu yang belajar sehingga proses pembelajaran cenderung didominasi oleh guru atau terpusat oleh guru (Cahyo, 2013:239). Hal ini yang menyebabkan kemampuan pemecahan masalah matematis siswa masih rendah.

Salah satu model pembelajaran yang dianggap tepat dan sesuai untuk meningkatkan kemampuan pemecahan masalah matematis dan keterampilan sosial siswa adalah pembelajaran kooperatif tipe STAD. Pembelajaran kooperatif tipe STAD dipilih karena model pembelajaran ini jarang diterapkan oleh guru di kelas. Selain itu, pada pembelajaran kooperatif tipe STAD siswa diajarkan untuk bekerja sama dalam suatu team atau kelompok, sehingga dengan sendirinya dapat memperbaiki hubungan sosial antara para siswa, mengembangkan keterampilanketerampilan proses kelompok dan pemecahan masalah (Louisell dan Descamps dalam Trianto, 2011 : 57).

Selanjutnya, beberapa penelitian yang relevan terkait dengan pembelajaran kooperatif tipe STAD telah dilakukan oleh Masitah (2013) dan oleh Rahayu (2014) yang menunjukkan bahwa peningkatan kemampuan pemecahan masalah matematis siswa yang diajar dengan pembelajaran koopertif tipe STAD lebih tinggi daripada kemampuan pemecahan masalah matematis siswa yang diajar dengan pembelajaran langsung. Berdasarkan penjelasan di atas, perlu diadakan penelitian tentang penerapan pembelajaran kooperatif tipe STAD sehingga peneliti tertarik untuk mengadakan penelitian dengan judul "Peningkatan Kemampuan Pemecahan Masalah Matematis Siswa SMP Melalui Pembelajaran Kooperatif tipe STAD". 


\section{MATEMATICS PAEDAGOGIC}

Vol II. No. 1, September 2017, hlm. 1 - 7

Available online at www.jurnal.una.ac.id/indeks/jmp

\section{METODE}

Jenis penelitian ini adalah penelitian eksperimen semu atau quasi eksperiment. Penelitian ini dilakukan di SMP Swasta Al Maksum yang berlokasi di Jalan Satria Dusun XI Cinta Rakyat. Kegiatan penelitian dilakukan pada semester ganjil Tahun Ajaran 2016/2017. Pelaksanaanny direncanakan berlangsung pada Desember 2016.

Populasi penelitian ini adalah seluruh siswa di sekolah SMP Swasta Al Washliyah Medan sedangkan sampel penelitian ini adalah siswa kelas VIII SMP Swasta Al Maksum Percut Sei Tuan. Sampel penelitian dipilih secara acak (cluster random sampling). Sampel yang terpilih yaitu siswa Kelas VIII A dan VIII B SMP Swasta Al Maksum Percut Sei Tuan yang berjumlah 66 orang. Kemudian dilakukan undian dari dua kelas tersebut untuk memilih sehingga terpilih kelas VIII (A) yang berjumlah 34 orang sebagai kelas eksperimen dengan menerapkan pembelajaran pembelajaran koperatif tipe STAD kemudian terpilih VIII (B) yang berjumlah 32 orang sebagai kelas kontrol dengan menerapkan pembelajaran langsung.

\section{Dalam penelitian ini}

melibatkan dua jenis variabel yaitu :

variabel bebas berupa pembelajaran dengan menggunakan pembelajaran koperatif tipe STAD dan pembelajaran langsung, variabel terikatnya adalah kemampuan pemecahan masalah matematis siswa.

Pada desain penelitian ini terdapat dua kelompok, untuk sampel yang diberikan perlakuan disebut kelompok eksperimen, sedangkan kelompok yang tidak mendapatkan perlakuan disebut kelompok kontrol.
Pada masing-masing kelompok pada awal pembelajaran akan diberikan pre test untuk mengukur kondisi awal berupa soal uraian. Adapun desain penelitian ini adalah sebagai berikut:

Kelompok Eksperimen $0_{1} \mathrm{X}_{2}$ Kelompok Kontrol $\quad 0_{1} \quad 0_{2}$ Keterangan :

$\mathbf{X}=$ Perlakuan berupa pembelajaran kooperatif tipe STAD

$0_{1}=$ Pre tes pemecahan masalah matematis

$\mathrm{O}_{2}=$ Post tes pemecahan masalah matematis

Instrumen penelitian yang digunakan dalam penelitian adalah tes. Instrumen jenis tes yaitu tes kemampuan pemecahan masalah (soal bentuk uraian). Selanjutnya data dianalisis dengan uji t.

\section{HASIL DAN PEMBAHASAN}

Pada sub bab ini akan diuraikan hasil analisis data kemampuan pemecahan masalah matematis siswa meliputi deskripsi pre tes kemampuan pemecahan masalah matematis, deskripsi post tes kemampuan pemecahan masalah serta deskripsi mengenai N-Gain kemampuan pemecahan masalah siswa. Selain itu akan diuraikan juga mengenai hasil uji normalitas dan uji homogenitas serta uji $t$ untuk data yang diperoleh.

Hasil pre tes pada kelas eksperimen diperoleh skor terendah 9, skor tertinggi 13 , rata-rata 11,26 dan standar deviasi sebesar 1,136. Sedangkan untuk pre tes di kelas kontrol diperoleh skor terendah 9, skor tertinggi 16 , rata-rata 11,44 dan standar deviasi sebesar 1,343. 


\section{MATEMATICS PAEDAGOGIC}

Vol II. No. 1, September 2017, hlm. 1 - 7

Available online at www.jurnal.una.ac.id/indeks/jmp

Berdasarkan hasil post tes pada kelas eksperimen diperoleh skor terendah 15 , skor tertinggi 19 , ratarata 17,03 dan standar deviasi sebesar 1. Sedangkan pada kelas kontrol diperoleh skor terendah 13, skor tertinggi postes 18 , rata-rata 15,13 dan standar deviasi sebesar 1,008. Jadi, dapat disimpulkan bahwa rata-rata skor kemampuan pemecahan masalah matematis baik pada kelas eksperimen dan kontrol terjadi peningkatan. Namun, jika dibandingkan skor ratarata pada kelas eksperimen lebih tinggi dibandingkan pada kelas kontrol.

Selanjutnya, nilai terendah $\mathrm{N}$ gain kelas eksperimen 0,429 dan kelas kontrol nilainya yaitu 0,250 . Nilai tertinggi $\mathrm{N}$-gain pada kelas eksperimen sebesar 0,889 dan pada kelas kontrol sebesar 0,556. Sedangkan untuk nilai rata-rata $\mathrm{N}$-gain kelas eksperimen sebesar 0,65668 dan kelas kontrol sebesar 0,42345. Jadi, rata-rata $\mathrm{N}$-gain kelas eksperimen lebih tinggi dibandingkan rata-rata $\mathrm{N}$ gain dikelas kontrol.

Dari perolehan ini maka selisih rata-rata $\mathrm{N}$-gain antara kelas ekperimen dan kelas kontrol sebesar 0,23323 . Selain itu, nilai standar deviasi untuk kelas eksperimen lebih tinggi dibandingkan standar deviasi pada kelas kontrol, yakni 0,079948 pada kelas eksperimen 0,118394 berarti skor N-gain kemampuan pemecahan masalah matematis siswa kelas eksperimen lebih menyebar dari pada skor N-gain kemampuan pemecahan masalah matematis siswa kelas kontrol.

Sebelum dilakukan analisis data uji $\mathrm{t}$ dari $\mathrm{N}$-Gain kemampuan pemecahan masalah matematis pada kelas eksperimen dan kelas kontrol terlebih dahulu dilakukan uji prasyarat yakni uji normalitas dan uji homogenitas dari $\mathrm{N}$-gain tersebut. Uji normalitas pada penelitian ini menggunakan teknik KolmogorovSmirnov sedangkan uji Homogenitasnya menggunakan Uji Levene.

Dari hasil uji KolmogorovSmirnov test tersebut, diketahui bahwa nilai signifikansi kelas eksperimen sebesar 0,200 sedangkan kelas kontrol 0,200 karena nilai signifikansi kelas eksperimen dan kelas kontrol sama yaitu $0,200>\alpha: 0,05$ maka data $\mathrm{N}$ gain kelas eksperimen dan kelas kontrol berdistribusi normal. Dengan demikian data $\mathrm{N}$-gain kemampuan pemecahan masalah matematis secara keseluruhan dapat disimpulkan berdistribusi normal.

Dari hasil Levene menggunakan program SPSS 16 tersebut, diketahui bahwa untuk dengan uji Levene nilai signifikansinya sebesar $0,967>\alpha$ : 0,05 sehingga hipotesis nol diterima yang berarti semua populasi mempunyai varians yang sama/homogen. Dengan demikian, data N-gain kemampuan pemecahan masalah matematis secara keseluruhan dapat disimpulkan memiliki varians yang sama atau homogen.

Setelah pengujian prasyarat analisis data di dapat bahwa N-Gain pemecahan masalah matematis berdistribusi normal dan homogen maka analisis yang digunakan adalah analisis parametrik dengan menggunakan uji t.

Berdasarkan hasil perhitungan dengan menggunakan uji t pada taraf signifikansi $\alpha=0,05$ menggunakan program SPSS diperoleh dapat diketahui bahwa nilai $\mathrm{F}$ pada faktor 


\section{MATEMATICS PAEDAGOGIC}

Vol II. No. 1, September 2017, hlm. 1 - 7

Available online at www.jurnal.una.ac.id/indeks/jmp

pembelajaran (pembelajaran kooperatif tipe STAD dan pembelajaran langsung) dengan nilai signifikansi 0,000 lebih kecil dari taraf signifikansi 0,05 sehingga $\mathrm{H}_{\mathrm{o}}$ ditolak. Dengan kata lain, terdapat perbedaan peningkatan kemampuan pemecahan masalah matematis antara siswa yang diberi pembelajaran kooperatif tipe STAD dibandingkan dengan siswa yang diberi pembelajaran langsung. Oleh karena itu, dapat disimpulkan peningkatan kemampuan pemecahan masalah matematis antara siswa yang memperoleh pembelajaran kooperatif tipe $S T A D$ lebih tinggi secara signifikan dibandingkan dengan siswa yang memperoleh pembelajaran langsung.

Berdasarkan hasil penelitian yang diperoleh maka akan dibahas hubungannya dengan tujuan yang telah ditetapkan. Berikut ini akan diuraikan beberapa faktor yang terkait dalam penelitian ini, yaitu faktor pembelajaran, kemampuan pemecahan masalah matematis. Secara lengkap uraian tersebut akan disajikan dalam bentuk deskripsi berikut ini.

\section{Faktor Pembelajaran}

Salah satu faktor yang paling berpengaruh terhadap kemampuan pemecahan masalah matematis siswa adalah pembelajaran khususnya pembelajaran kooperatif tipe $S T A D$. Pembelajaran kooperatif tipe STAD yang diterapkan pada kelas eksperimen dimulai dari pembagian kelompok siswa yang heterogen yang terdiri atas 4-6 orang tiap kelompoknya. Tujuan pembentukan kelompok untuk memberi kesempatan kepada setiap siswa untuk berpikir, berinteraksi dan terlibat aktif dalam kegiatan belajar. Hal ini berbeda dengan kelas kontrol yang mana guru menjelaskan materi kepada siswa sehingga menyebabkan siswa kurang berinteraksi dan pasif dalam kegiatan pembelajaran.

Selanjutnya, pada kelas eksperimen guru membagi siswa ke dalam beberapa kelompok untuk menyelesaikan permasalahan. Siswa bekerjasama dan berdiskusi serta saling bertukar pendapat untuk menyelesaikan permasalahan yang diberrikan oleh guru berasarkan pengetahuan dan sumber belajar yang mereka miliki. Hal ini menyebabkan setiap anggota kelompok terlibat secara aktif dalam diskusi dan siswa saling berbagi bertukar ide pikiran melalui tanya jawab. Hal ini berbeda dengan pembelajaran pada kelas kontrol siswa hanya bertanya kepada guru dan kondisi pembelajaran tidak memungkinkan terjadinya tukar pikiran antar siswa.

Berdasarkan uraian di atas dari kedua pembelajaran ini terdapat perbedaan pada proses pembentukan pengetahuan yang dilakukan guru. Perbedaan inilah yang dianggap mendukung hasil penelitian yang menunjukkan bahwa pembelajaran kooperatif tipe STAD efektif untuk meningkatkan kemampuan pemecahan masalah siswa daripada pembelajaran langsung.

\section{Kemampuan Pemecahan \\ Masalah Matematis}

Kemampuan pemecahan masalah matematis adalah merupakan proses menerapkan pengetahuan yang telah diperoleh sebelumnya pada situasi baru dan berbeda yang meliputi kemampuan siswa memahami masalah, merencanakan penyelesaian, menyelesaikan masalah sesuai rencana dan memeriksa kembali prosedur hasil penyelesaian. 


\section{MATEMATICS PAEDAGOGIC}

Vol II. No. 1, September 2017, hlm. 1 - 7

Available online at www.jurnal.una.ac.id/indeks/jmp

Dari hasil penelitian ini diperoleh bahwa $\mathrm{N}$-gain kemampuan pemecahan masalah matematis siswa yang memperoleh pembelajaran kooperatif tipe STAD sebesar 0,65668 dan pada siswa yang diajarkan dengan pembelajaran langsung 0,42345 . Hal ini menunjukkan bahwa peningkatan kemampuan pemecahan masalah matematis siswa yang diajarkan dengan pembelajaran kooperatif tipe jigsaw lebih tinggi daripada siswa yang diajarkan dengan pembelajaran langsung.

Berdasarkan pengujian dengan menggunakan uji anava dua jalur maka diperoleh kemampuan pemecahan masalah matematis dengan nilai signifikan (sig) $\alpha=0,000$. Karena taraf nilai signifikan kemampuan pemecahan masalah matematis lebih kecil dari $\alpha=0,05$, maka dapat disimpulkan bahwa peningkatan kemampuan pemecahan masalah matematis siswa yang diajarkan dengan pembelajaran pemecahan masalah matematis lebih tinggi daripada siswa yang diajarkan dengan pembelajaran langsung.

\section{DAFTAR RUJUKAN}

Cahyo, A. N. 2013. Panduan Aplikasi Teori-Teori Belajar Mengajar Teraktual dan Terpopuler. Yogyakarta: Diva Press.

Masitah. 2013. Penerapan Model Pembelajaran Kooperatif Tipe STAD untuk Meningkatkan Kemampuan Pemecahan Masalah dan Sikap Positif Matematis Siswa MTs. Medan: Tesis PPs UNIMED. Tidak diterbitkan.
Pernyataan ini didukung juga oleh hasil penelitian Astuti (2016) bahwa Suprapto (2015) bahwa kemampuan pemecahan masalah matematis siswa yang memperoleh pembelajaran kooperatif tipe STAD lebih baik dibandingkan dengan siswa yang memperoleh pembelajaran konvensional. Simpulan penelitian ini menunjukkan bahwa kemampuan pemecahan masalah dengan menggunakan model pembelajaran kooperatif tipe STAD pada strata pendidikan siswa yang lebih tinggi.

\section{SIMPULAN}

Berdasarkan rumusan masalah, hasil penelitian, dan pembahasan seperti yang telah dikemukakan sebelumnya, diperoleh bahwa peningkatan kemampuan pemecahan masalah matematis siswa yang diberi pembelajaran kooperatif tipe STAD lebih tinggi daripada siswa yang diberi pembelajaran langsung.

Rahayu, R. 2014. Peningkatan Kemampuan Pemecahan Masalah dan Komunikasi Matematis Siswa SMP Percut Ar Rahman Percut Melalui Pembelajaran Kooperatif Tipe STAD. Medan: Tesis PPs UNIMED. Tidak diterbitkan.

Sari, S., Elniati, S., dan Fauzan, A. 2014. Pengaruh Pembelajaran Berbasis Masalah Terhadap Kemampuan Pemecahan Masalah 
Vol II. No. 1, September 2017, hlm. 1 - 7

Available online at www.jurnal.una.ac.id/indeks/jmp

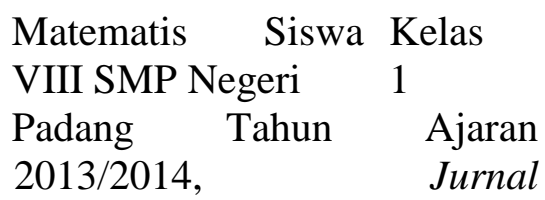

Pendidikan Matematika. Vol.

2,No.3,(Online),

(ejournal.unp.ac.id/students/in

dex.php/pmat/article/download /.../882, diakses 19 Juni 2015).

Suprapto. 2015. Pengaruh Model Pembelajaran Kooperatif tipe STAD terhadap

Peningkatan Kemampuan Representasi dan Pemecahan Masalah Matematis

Siswa. Indonesian Digital Journal of Mathematics and
Education. Vol. 2 No. 3, (Online),(dealmathedu.p4tkma tematika.org/wpcontent/upload s/2016/01/3_Suprapto.pdf, diakses 19 Desember 2016)

Susanto, A. 2013. Teori Belajar dan Pembelajaran di Sekolah Dasar. Jakarta: $\quad$ Prenada Media Group.

Trianto. 2011. Mendesain Model Pembelajaran InovatifProgresif: Konsep, Landasan, dan Implementasinya pada Kurikulum Tingkat Satuan Pendidikan. Jakarta : Kencana 